\title{
Thermal analysis, phase transitions and molecular reorientations in $\left[\mathrm{Fe}\left(\mathrm{OS}\left(\mathrm{CH}_{3}\right)_{2}\right)_{6}\right]\left(\mathrm{ClO}_{4}\right)_{2}$
}

\author{
${\text { Elżbieta } \text { Szostak }^{1} \text { (D) Anna Migdał-Mikuli }}^{1}$
}

Received: 6 October 2016/Accepted: 7 February 2017/Published online: 24 February 2017

(C) The Author(s) 2017. This article is published with open access at Springerlink.com

\begin{abstract}
Thermogravimetric analysis connected with quadruple mass spectroscopy (TG/MS) for an identification of $\left[\mathrm{Fe}\left(\mathrm{OS}\left(\mathrm{CH}_{3}\right)_{2}\right)_{6}\right]\left(\mathrm{ClO}_{4}\right)_{2}$ decomposition products, carried out to determine its thermal stability, has indicated that the title compound does not change its mass till ca. $385 \mathrm{~K}$. Above this temperature, it starts slowly to lose a part of $\left(\mathrm{CH}_{3}\right)_{2} \mathrm{SO}$ ligands, which begins to form a liquid phase, in which the title compound partially dissolves. Finally, at ca. $476 \mathrm{~K}$, when two from six coordinated $\left(\mathrm{CH}_{3}\right)_{2} \mathrm{SO}$ were detached from central atom, the $\left[\mathrm{Fe}\left(\mathrm{OS}\left(\mathrm{CH}_{3}\right)_{2}\right)_{4}\right]\left(\mathrm{ClO}_{4}\right)_{2}$ is formed. At ca. $514 \mathrm{~K}$ this sample explodes. Differential scanning calorimetry (DSC) measurements performed in the temperature range of 100-443 K revealed existence of two anomalies on DSC curves. The first, a big one, at $T_{\mathrm{c}} \approx 338 \mathrm{~K}$ is associated with the phase transition: crystal phase Cr. $1 \leftrightarrow$ rotational phase Rot. 1 , and the second, a small one, at $T_{\mathrm{m} 1} \approx 414 \mathrm{~K}$ is associated with two parallel processes, which are: decomposition of $\left[\mathrm{Fe}\left(\mathrm{OS}\left(\mathrm{CH}_{3}\right)_{2}\right)_{6}\right]$ $\left(\mathrm{ClO}_{4}\right)_{2}$ with the DMSO release and dissolution of $\left[\mathrm{Fe}\left(\mathrm{OS}\left(\mathrm{CH}_{3}\right)_{2}\right)_{6-\mathrm{x}}\right]\left(\mathrm{ClO}_{4}\right)_{2}$ in DMSO. The large value of solid-solid phase transition entropy change $\left(\Delta S_{\mathrm{c}} \approx\right.$ $\left.79.3 \mathrm{~J} \mathrm{~mol}^{-1} \mathrm{~K}^{-1}\right)$ and small value of the melting process $\left(\Delta S_{\mathrm{m}} \approx 5.8 \mathrm{~J} \mathrm{~mol}^{-1} \mathrm{~K}^{-1}\right)$ indicate on such large configurational disorder in the high-temperature phase that this phase can be considered as a rotational phase (so called also as "plastic crystals"). The results of the vibrational and reorientational dynamics of $\left(\mathrm{CH}_{3}\right)_{2} \mathrm{SO}$ ligands and $\mathrm{ClO}_{4}^{-}$ anions in the high- and low-temperature phases of $\left[\mathrm{Fe}\left(\mathrm{OS}\left(\mathrm{CH}_{3}\right)_{2}\right)_{6}\right]\left(\mathrm{ClO}_{4}\right)_{2}$, investigated by Fourier transform
\end{abstract}

Elżbieta Szostak

szostak@chemia.uj.edu.pl

1 Faculty of Chemistry, Jagiellonian University, ul. Ingardena 3, 30-060 Kraków, Poland infrared absorption spectroscopy, show that even in the lowtemperature phase the $\mathrm{CH}_{3}$ groups in $\left(\mathrm{CH}_{3}\right)_{2} \mathrm{SO}$ ligands and also the $\mathrm{ClO}_{4}^{-}$anions perform fast (correlation time $\tau_{\mathrm{R}} \approx 10^{-12} \mathrm{~s}$ ) reorientational motions. These reorientational motions above $T_{\mathrm{c}}$ temperature became so fast that in the rotational phase they turn into nearly free rotational motions.

Keywords Thermal analysis (TG/QMS) · Phase transitions · Vibrational and rotational motions · DSC . Fourier transform infrared absorption spectroscopy (FT-IR)

\section{Introduction}

The rich and diverse polymorphism of compounds of the type: $\left[\mathrm{M}(\mathrm{DMSO})_{6}\right]\left(\mathrm{ClO}_{4}\right)_{2}$ (where $\mathrm{M}=\mathrm{Cd}, \mathrm{Co}, \mathrm{Mn}, \mathrm{Zn}$, $\mathrm{Ni}, \mathrm{Mg}, \mathrm{Sr}$ and $\left.\mathrm{DMSO}=\left(\mathrm{CH}_{3}\right)_{2} \mathrm{SO}\right)$ was the subject of our interest since 2003 [1-7]. We have found that these substances possess both orientationally ordered and highly disordered crystal phases. Some from those just recently mentioned are rotational phases, so-called plastic crystals. Certain from the all detected phases have stable and another have metastable character.

According to Selbin et al. [8] and Currier and Weber [9] title compound precipitated as a pale yellow crystals and explodes in the vicinity of $423 \mathrm{~K}$. Its infrared absorption spectrum suggests that DMSO ligands are bonded to a central metal through the oxygen atom [8-10]. Berney and Weber [10] have claimed that the study of $\left[\mathrm{Fe}\left(\mathrm{OS}\left(\mathrm{CH}_{3}\right)_{2}\right)_{6}\right]\left(\mathrm{ClO}_{4}\right)_{2}$ is difficult because of its rapid decomposition.

The general aim of the present study is to discover the polymorphism of the fresh synthesized $\left[\mathrm{Fe}\left(\mathrm{OS}\left(\mathrm{CH}_{3}\right)_{2}\right)_{6}\right]$ $\left(\mathrm{ClO}_{4}\right)_{2}$ sample. The temperature ranges of DSC measurement will be selected based on the results obtained by 
thermogravimetric method. Additional aim of conducted research is to find connections between those detected phase transitions and eventual changes in the speed of stochastic reorientational motions of DMSO ligands and $\mathrm{ClO}_{4}^{-}$anions and/or with eventual a change of the crystal structure. We would like to draw these information by means of Fourier transform infrared absorption spectroscopy measurements performed in a function of temperature at cooling and heating the title compound.

\section{Experimental}

Preparation procedure of a polycrystalline sample was analogical to the synthesis of the analogous compounds with DMSO ligands [1-7]. Chemical composition of the synthesized sample was analysed by determination of percentage content of carbon, hydrogen and sulphur using an EURO EA 3000 elemental analyser with the accuracy of $\pm 0.3 \%$. Theoretical contents: C, $19.92 \%$; H, 5.01\%; S, 26.59\%. Found: $\mathrm{Mg}, 3.32 \%$; C, 19.33\%; S, 26.24\%. The elemental analysis of the title compound confirmed the presence of the stoichiometric number of six DMSO molecules in the complex cation.

Thermal analysis of the examined compound was made first of all in order to check its thermal stability. The thermogravimetric (TG/DTG) measurements were performed using a Mettler Toledo TGA/SDTA $851^{\mathrm{e}}$ apparatus. A sample weighing $3.6581 \mathrm{mg}$ was placed in a $150-\mu \mathrm{Al}_{2} \mathrm{O}_{3}$ crucible. The measurements were made in a flow of argon ( $\mathrm{Ar} \mathrm{6.0}$; $80 \mathrm{~cm}^{3} \mathrm{~min}^{-1}$ ) from 293 up to $651 \mathrm{~K}$ with a constant heating rate of $10 \mathrm{~K} \mathrm{~min}^{-1}$. The temperature was measured by a Pt$\mathrm{Pt} / \mathrm{Rh}$ thermocouple with the accuracy of $\pm 0.5 \mathrm{~K}$. Evolved gaseous products from the decomposition of the compound were identified using a ThermoStar GSD300T Balzers quadruple mass spectrometer (QMS). The temperature calibration of the TG instrument was done by using indium, zinc and aluminium melting points temperature and compares them with the literature values. Its accuracy is equal to $10^{-6} \mathrm{~g}$. The mass spectrometer was operated in electron impact mode (EI) using channeltron as a detector. Screening analyses were performed in the selected ion monitoring (SIM) mode.

The DSC measurements of $\left[\mathrm{Fe}\left(\mathrm{OS}\left(\mathrm{CH}_{3}\right)_{2}\right)_{6}\right]\left(\mathrm{ClO}_{4}\right)_{2}$ compound were made for two samples using two different DSC instruments. A Perkin-Elmer PYRIS 1 DSC instrument was used in the temperature range of 100-443 K (sample $\mathrm{A}=6.16 \mathrm{mg}$ ). A Mettler Toledo DSC 821e instrument was used in the temperature range of 298-443 K (sample: B $=6.26 \mathrm{mg}$ ). The details of the DSC experiment were the same as described in [11].

The infrared absorption measurements were performed using a Bruker VERTEX 70v Fourier transform infrared spectrometer in the spectral ranges of: 4000-400 (for FT-
MIR) and 400-50 $\mathrm{cm}^{-1}$ (FT-FIR), and with a resolution of $2 \mathrm{~cm}^{-1}$. The FT-FIR spectra were recorded for the sample suspended in Apiezon grease and placed on polyethylene window. The FT-MIR spectra were recorded for the sample mixed with Nujol and placed between two $\mathrm{KBr}$ pellets. An Advanced Research System (ARS) helium DE-202A cryostat and water-cooled helium ARS-2HW compressor working in a closed cycle manner, with controlled heating and cooling rates and temperature stabilization within $\pm 0.2 \mathrm{~K}$, were used to obtain the spectra at high temperatures. The temperature of the "cold finger" was measured with an accuracy of $\pm 1 \mathrm{~K}$, but the sample temperature, in particular, in a high-temperature range could have been several Kelvin higher.

\section{Results and discussion}

\section{Thermogravimetric analysis}

Figure 1 shows TG and DTG curves recorded for $[\mathrm{Fe}(\mathrm{OS}$ $\left.\left.\left(\mathrm{CH}_{3}\right)_{2}\right)_{6}\right]\left(\mathrm{ClO}_{4}\right)_{2}$ in a flow of Argon at a constant heating rate of $10 \mathrm{~K} \mathrm{~min}^{-1}$ in the temperature range of 290-650 K. Obtained results indicate that the compound does not change its mass till ca. $385 \mathrm{~K}$. Above this temperature, $\left[\mathrm{Fe}\left(\mathrm{OS}\left(\mathrm{CH}_{3}\right)_{2}\right)_{6}\right]\left(\mathrm{ClO}_{4}\right)_{2}$ starts to decompose. In the first stage of the thermal decomposition, which take place within the temperature range 385-447 K, two molecules of dimethylsulfoxide are released and $\left[\mathrm{Fe}\left(\mathrm{OS}\left(\mathrm{CH}_{3}\right)_{2}\right)_{4}\right]\left(\mathrm{ClO}_{4}\right)_{2}$ is formed. This compound is stable up to $476 \mathrm{~K}$, and then, it starts to lose next DMSO molecules. Suddenly, just above $514 \mathrm{~K}$ intense decomposition of created substance connected with an explosion takes place.

Figure 2 presents TG curve and QMS curves of the particular gaseous products of $\left[\mathrm{Fe}\left(\mathrm{OS}\left(\mathrm{CH}_{3}\right)_{2}\right)_{6}\right]\left(\mathrm{ClO}_{4}\right)_{2}$ thermal decomposition. During the TG experiment, the QMS spectra of masses were followed from $m / e=10$ to 80; however, for reasons of graphic clarity, only the masses of $m / e=15,16,28,44,48$, and 35 representing: $\mathrm{CH}_{3}, \mathrm{O}$ or $\mathrm{CH}_{4}, \mathrm{CO}$ or $\mathrm{C}_{2} \mathrm{H}_{4}, \mathrm{CO}_{2}, \mathrm{SO}$ and $\mathrm{Cl}^{-}$are shown in Fig. 2.

The QMS spectra indicate that within the temperature range $385-513 \mathrm{~K}$ title compound lose mainly DMSO molecules, what was registered as a distinct peak at the $m / e=15\left(\mathrm{CH}_{3}\right)$ line and rather small anomaly at $m / e=44$ $\left(\mathrm{CS} / \mathrm{CO}_{2}\right)$ line. At the temperature $514 \mathrm{~K}$ (explosion of the sample) besides the products of DMSO decomposition (signals $m / e=28,44,48,15$ i 16), the chlorine and oxygen molecules from decomposition of perchlorate anions are additionally emitted (signals $m / e=35,16$ ).

\section{DSC measurements}

The DSC curves were obtained for two $[\mathrm{Fe}(\mathrm{OS}$ $\left.\left.\left(\mathrm{CH}_{3}\right)_{2}\right)_{6}\right]\left(\mathrm{ClO}_{4}\right)_{2}$ samples $(\mathrm{A}$ and $\mathrm{B})$ with different masses. The results have not shown any significant changes in the 
Fig. 1 Mass loss valuated on TG curve of the $\left[\mathrm{Fe}\left(\mathrm{OS}\left(\mathrm{CH}_{3}\right)_{2}\right)_{6}\right]\left(\mathrm{ClO}_{4}\right)_{2}$ sample measured in the temperature range of $290-650 \mathrm{~K}$
Fig. 2 TG and QMS curves of thermal decomposition of $\left[\mathrm{Fe}\left(\mathrm{OS}\left(\mathrm{CH}_{3}\right)_{2}\right)_{6}\right]\left(\mathrm{ClO}_{4}\right)_{2}$
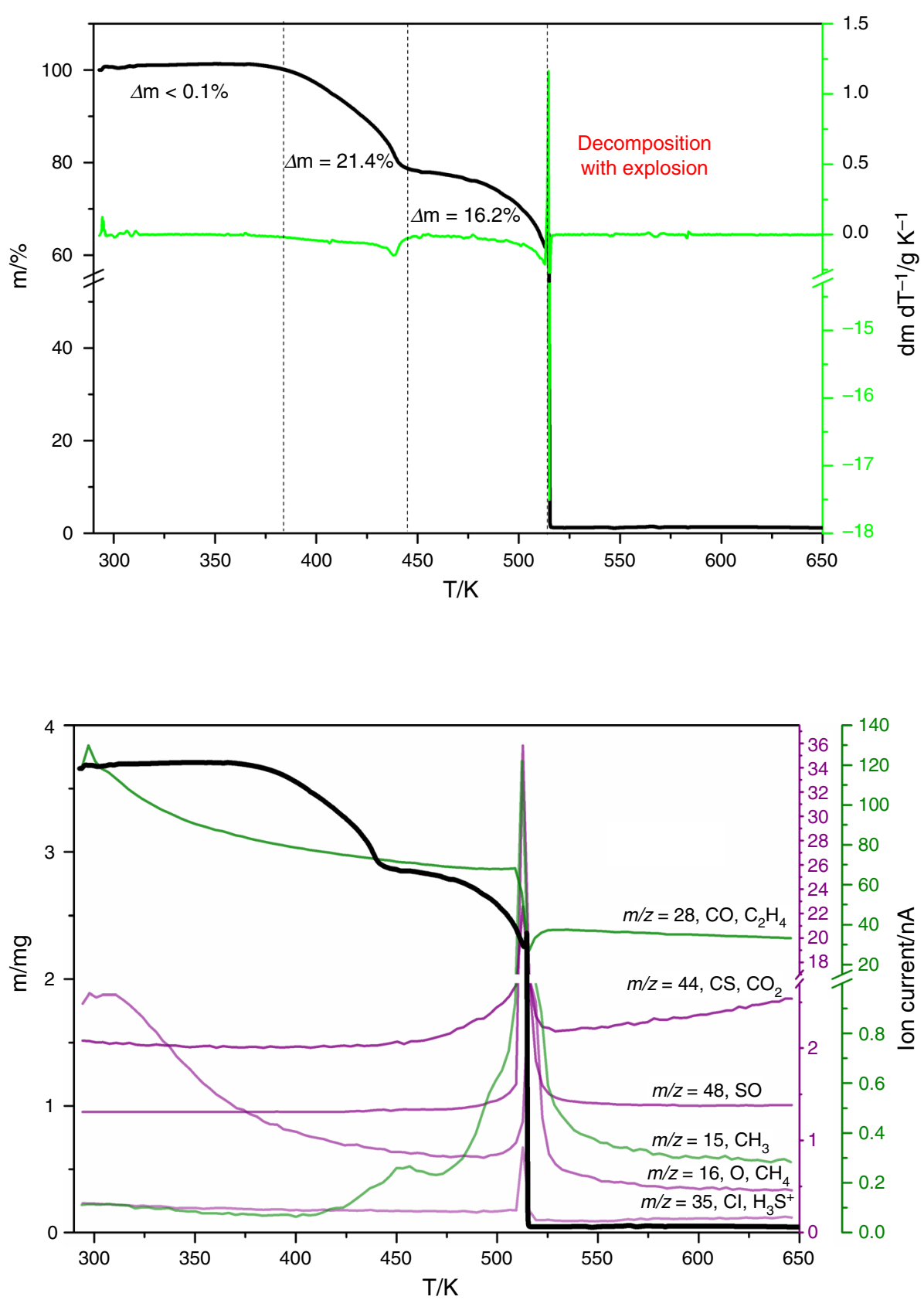

character of the DSC curves, so we will present here only the results obtained for sample A. The measurements were performed with different scanning rate and also with initial and final heating and cooling conditions, in order to check whether synthesized compound can create such metastable phases like did other previously studied compounds of $\left[\mathrm{M}\left(\mathrm{OS}\left(\mathrm{CH}_{3}\right)_{2}\right)_{6}\right]\left(\mathrm{ClO}_{4}\right)_{2}$ type [1-7].

Figure 3 presents the temperature dependences of the heat flow (DSC curves) obtained on heating (upper curve) and on cooling (lower curve) of the sample A in the temperature range $100-385 \mathrm{~K}$. One distinct anomaly was registered on each of these two DSC curves at:
$T_{\text {onset }}^{\mathrm{h}}=338.3$ and $T_{\text {onset }}^{\mathrm{c}}=338.3 \mathrm{~K}$ (where indexes $\mathrm{h}$ and $\mathrm{c}$ denote heating and cooling of the sample, respectively). The phase transitions temperatures determined for the sample $B$ were as follows: $T_{\text {onset }}^{\mathrm{h}}=337.3$ and $T_{\text {onset }}^{\mathrm{c}}=337.4 \mathrm{~K}$. The mean values of the phase transition temperature are: $T_{\mathrm{c}}^{\mathrm{h}}=338.3 \pm 0.3 \mathrm{~K}$ (at heating) and at $T_{\mathrm{c}}^{\mathrm{c}}=338.3 \pm 0.3 \mathrm{~K}$ (at cooling) with the estimated entropy change $\Delta S_{\mathrm{c}} \approx 79.3 \pm 6.2 \mathrm{~J} \mathrm{~mol}^{-1} \mathrm{~K}^{-1}$. The large value of transition entropy change indicates considerable configurational disorder in the high-temperature phase (socalled ODIC crystals [1-7, 12]). The absence of hysteresis of the phase transition temperature at $T_{\mathrm{c}}$ and sharpness of 


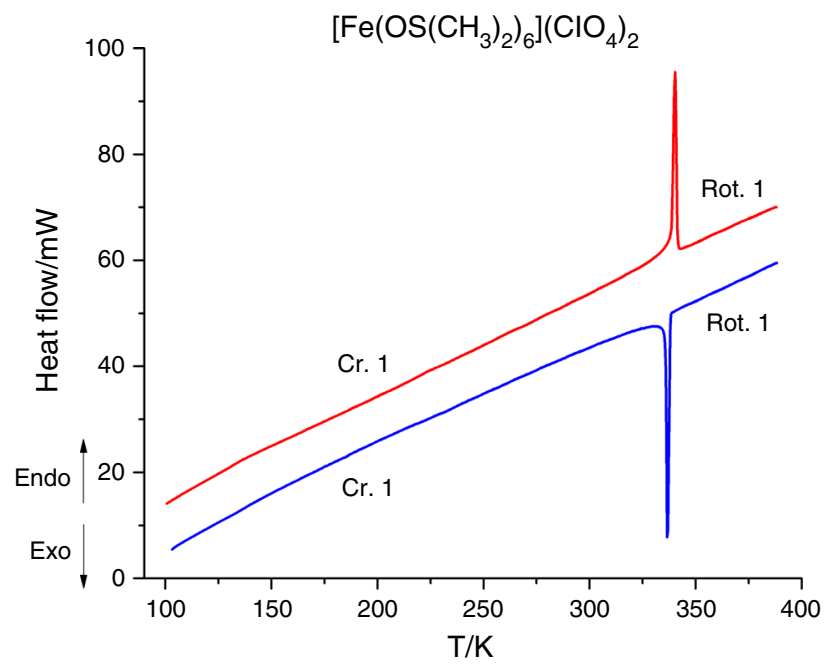

Fig. 3 DSC curves registered in the temperature range of 100-385 K during heating and cooling of $\left[\mathrm{Fe}\left(\mathrm{OS}\left(\mathrm{CH}_{3}\right)_{2}\right)_{6}\right]\left(\mathrm{ClO}_{4}\right)_{2}$ with a scanning rate of $20 \mathrm{~K} \mathrm{~min}^{-1}$

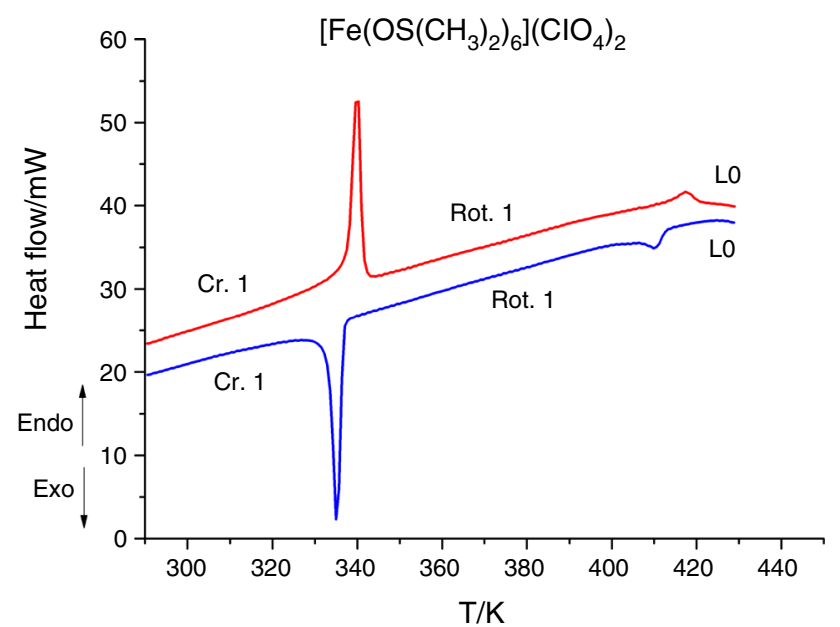

Fig. 4 DSC curves registered in the temperature range of 290-443 K during heating and cooling of $\left[\mathrm{Fe}\left(\mathrm{OS}\left(\mathrm{CH}_{3}\right)_{2}\right)_{6}\right]\left(\mathrm{ClO}_{4}\right)_{2}$ with a scanning rate of $40 \mathrm{~K} \mathrm{~min}^{-1}$

the anomaly suggest that the detected phase transition is of the second-order type. Thus, the title compound has two solid phases in the temperature range of 100-385 K: high temperature (phase Rot. 1) and low temperature (phase Cr. 1). It is very interesting that in the high-temperature phase of $\left[\mathrm{Fe}\left(\mathrm{OS}\left(\mathrm{CH}_{3}\right)_{2}\right)_{6}\right]\left(\mathrm{ClO}_{4}\right)_{2}$, regardless of a scanning rate, does not transform into the metastable phase while the sample was cooled down, opposite to other investigated by us earlier compounds of the type: $\left[\mathrm{M}\left(\mathrm{OS}\left(\mathrm{CH}_{3}\right)_{2}\right)_{6}\right]\left(\mathrm{ClO}_{4}\right)_{2}$ [1-7].

Figure 4 presents DSC curves obtained during heating and cooling of the sample A from 290 to $443 \mathrm{~K}$ with a scanning rate of $40 \mathrm{~K} \mathrm{~min}^{-1}$. At the temperature range of 290-385 K, we can see a very big and sharp anomaly at $T_{\mathrm{c}}$ connected with the phase transition: phase $\mathrm{Cr}$. $1 \rightarrow$ phase Rot. 1. Later, while heating hermetically closed sample A, being in the Rot. 1 phase, up to $443 \mathrm{~K}$, it experiences a reversible phase transition at $T_{\mathrm{m} 1}=414.1 \pm 0.4 \mathrm{~K}$ into the phase named L0. This phase transition is observed as a small and broad anomaly on DCS curve. The entropy change calculated for this phase transition is $\Delta S_{\mathrm{m}} \approx 5.8 \pm 0.5 \mathrm{~K} \mathrm{~J} \mathrm{~mol}^{-1} \mathrm{~K}^{-1}$. The thermodynamic parameters of the detected phase transitions obtained during heating are presented in Table 1 .

It is not possible to determine the nature of the observed phases only on the basis of DSC measurements. However, using a microscope we have observed that phases $\mathrm{Cr}$. 1 and Rot. 1 were the solid phases and L0 is partially melted phase. Taking into account the findings from thermal analysis, we can postulate that at $T_{\mathrm{m} 1}$ the sample became partially dissolved in liquid DMSO, which arises out from the thermal decomposition of $\left[\mathrm{Fe}\left(\mathrm{OS}\left(\mathrm{CH}_{3}\right)_{2}\right)_{6}\right]\left(\mathrm{ClO}_{4}\right)_{2}$ to $\left[\mathrm{Fe}\left(\mathrm{OS}\left(\mathrm{CH}_{3}\right)_{2}\right)_{4}\right]\left(\mathrm{ClO}_{4}\right)_{2} \quad$ (compare "Thermogravimetric analysis" section), because the sample is at this DSC experiment hermetically closed in the calorimetric vessel. Moreover, it was concluded from the large value of the entropy change of the phase transition $\Delta S_{\mathrm{c}}$ (see Table 1) that phase $\mathrm{Cr}$. 1 is orientationally dynamically disordered crystal, so-called ODIC, and phase Rot. 1 is more likely rotational phase, so-called plastic crystal.

\section{Vibrational spectra}

The $\left[\mathrm{Fe}\left(\mathrm{OS}\left(\mathrm{CH}_{3}\right)_{2}\right)_{6}\right]^{2+}$ complex cation can be described in the $S_{6}$ point group, with the normal vibrations belonging to the symmetry species $\Gamma_{\mathrm{vib}}=29 A_{\mathrm{g}}+29 E_{\mathrm{g}}+30 A_{\mathrm{u}}+30$ $E_{\mathrm{u}}\left(\right.$ or $\Gamma^{\prime}{ }_{\mathrm{vib}}=11 A_{\mathrm{g}}+12 A_{\mathrm{u}}+11 E_{\mathrm{g}}+12 E_{\mathrm{u}}$ considering the methyl groups as point masses). The "g" modes are Raman active whereas the " $u$ " modes are IR active $[10,13,14]$.

Table 1 Thermodynamic parameters of the detected phase transitions obtained at heating $\left(T_{\mathrm{c}}^{\mathrm{h}}\right)$ and at cooling $\left(T_{\mathrm{c}}^{\mathrm{c}}\right)$ of $\left.\left[\mathrm{Fe}\left(\mathrm{OS}_{(\mathrm{CH}}\right)_{2}\right)_{6}\right]\left(\mathrm{ClO}_{4}\right)_{2}$

\begin{tabular}{|c|c|c|c|c|c|}
\hline & \multirow[t]{2}{*}{ Phase transition } & \multicolumn{4}{|c|}{$\left[\mathrm{Fe}\left(\mathrm{OS}\left(\mathrm{CH}_{3}\right)_{2}\right)_{6}\right]\left(\mathrm{ClO}_{4}\right)_{2}$} \\
\hline & & $\overline{T_{\mathrm{c}}^{\mathrm{h}} / \mathrm{K}}$ & $T_{\mathrm{c}}^{\mathrm{c}} / \mathrm{K}$ & $\Delta H / \mathrm{kJ} \mathrm{mol}^{-1}$ & $\Delta S / \mathrm{J} \mathrm{mol}^{-1} \mathrm{~K}^{-1}$ \\
\hline$T_{\mathrm{m} 1}$ & Rot. $1 \leftrightarrow$ L0 & $414.1 \pm 0.4$ & $413.2 \pm 0.5$ & $2.45 \pm 0.17$ & $5.8 \pm 0.5$ \\
\hline$T_{\mathrm{c}}$ & Cr $1 \leftrightarrow$ Rot. 1 & $338.3 \pm 0.3$ & $338.3 \pm 0.3$ & $26.79 \pm 2.09$ & $79.3 \pm 6.2$ \\
\hline
\end{tabular}


Table 2 Comparison of the band positions of the infrared spectra of solid $\left[\mathrm{Fe}\left(\mathrm{OS}\left(\mathrm{CH}_{3}\right)_{2}\right)_{6}\right]\left(\mathrm{ClO}_{4}\right)_{2}$ and liquid DMSO at room temperature IR of solid $\left[\mathrm{Fe}\left(\mathrm{OS}\left(\mathrm{CH}_{3}\right)_{2}\right)_{6}\right]\left(\mathrm{ClO}_{4}\right)_{2}$ and liquid DMSO at room temperature

\begin{tabular}{|c|c|c|c|}
\hline This paper in: ${ }^{a}$ Apiezon, ${ }^{b}$ Nujol & Literature data $[8-10,15]$ & DMSO literature data $[13,15-17]$ & Tentative assignments \\
\hline $52 \mathrm{~m}^{\mathrm{a}}$ & & & $v_{\mathrm{L}}$ (lattice) \\
\hline $76 \mathrm{~m}^{\mathrm{a}}$ & & & $v_{\mathrm{L}}$ (lattice) \\
\hline $86 \mathrm{~m}^{\mathrm{a}}$ & & & $v_{\mathrm{L}}$ (lattice) \\
\hline $112 w^{a}$ & & & $\gamma(\mathrm{FeOS})$ \\
\hline $127 w^{a}$ & & & $\gamma(\mathrm{FeOS})$ \\
\hline $155 \mathrm{w}^{\mathrm{a}}$ & & $157 \mathrm{w}$ & $\mathrm{T}\left(\mathrm{CH}_{3}\right)$ \\
\hline $182 \mathrm{~m}^{\mathrm{a}}$ & & & $\mathrm{T}(\mathrm{CS})$ \\
\hline $212 \mathrm{~m}^{\mathrm{a}}$ & & & $\mathrm{T}(\mathrm{CS})$ \\
\hline $227 \mathrm{~m}^{\mathrm{a}}$ & $225 \mathrm{w}$ & & $\mathrm{T}(\mathrm{CS})$ \\
\hline $265 \mathrm{sh}^{\mathrm{a}}$ & $262 \mathrm{~m}$ & & $\delta(\mathrm{CSC})$ \\
\hline $286 \mathrm{~m}^{\mathrm{a}}$ & & & $\delta(\mathrm{CSC})$ \\
\hline $319 \mathrm{~m}^{\mathrm{a}}$ & $320 \mathrm{sh}$ & $307 \mathrm{w}$ & $\omega(\mathrm{CSC})$ \\
\hline $339 \mathrm{vs}^{\mathrm{a}}$ & $340 \mathrm{~m}$ & $335 \mathrm{~m}$ & $\tau(\mathrm{CSC})$ \\
\hline $363 \mathrm{~m}^{\mathrm{a}}$ & & $383 \mathrm{~m}$ & $\delta(\mathrm{CSC})$ \\
\hline $402 \mathrm{sh}^{\mathrm{a}}$ & $402 \mathrm{sh}$ & & $v_{\mathrm{s}}(\mathrm{FeO})$ \\
\hline $414 \mathrm{~s}^{\mathrm{a}}$ & $415 \mathrm{~m}$ & & $v_{\mathrm{s}}(\mathrm{FeO})$ \\
\hline $437 \mathrm{~s}^{\mathrm{a}, \mathrm{b}}$ & $438 \mathrm{~m}$ & & $v_{\text {as }}(\mathrm{FeO})$ \\
\hline $477 \mathrm{~m}^{\mathrm{a}, \mathrm{b}}$ & & & $v_{\mathrm{s}}(\mathrm{FeO})$ \\
\hline $620 \mathrm{~m}^{\mathrm{b}}$ & $623 \mathrm{~m}$ & & $\delta_{\mathrm{d}}(\mathrm{OClO}) \mathrm{F}_{2}$ \\
\hline $677 w^{b}$ & $670 \mathrm{vw}$ & $670 \mathrm{~m}$ & $v_{\mathrm{s}}(\mathrm{CS})$ \\
\hline $711 \mathrm{~m}^{\mathrm{b}}$ & $720 \mathrm{~m}$ & $700 \mathrm{~m}$ & $v_{\mathrm{as}}(\mathrm{CS})$ \\
\hline \multicolumn{4}{|l|}{$718 \mathrm{~m}^{\mathrm{b}}$} \\
\hline $901 \mathrm{vw}^{\mathrm{b}}$ & & $900 \mathrm{vw}$ & $\rho\left(\mathrm{CH}_{3}\right)$ \\
\hline $936 \mathrm{vs}^{\mathrm{b}}$ & 931 vs & & $v_{\mathrm{s}}(\mathrm{ClO}) \mathrm{A}_{1}$ \\
\hline $950 \mathrm{sh}^{\mathrm{b}}$ & $950 \mathrm{~s}$ & & $\rho\left(\mathrm{CH}_{3}\right)$ \\
\hline $959 \mathrm{sh}^{\mathrm{b}}$ & & 957 vs & $v_{\mathrm{s}}(\mathrm{SO})$ \\
\hline $969 \mathrm{vw}^{\mathrm{b}}$ & 989 vs & & $v_{\mathrm{s}}(\mathrm{SO})$ \\
\hline \multicolumn{4}{|l|}{$988 \mathrm{sh}^{\mathrm{b}}$} \\
\hline $999 \mathrm{~s}^{\mathrm{b}}$ & & $1006 \mathrm{~m}$ & $\rho\left(\mathrm{CH}_{3}\right)$ \\
\hline $1019 \mathrm{sh}^{\mathrm{b}}$ & & $1012 \mathrm{~s}$ & $\rho\left(\mathrm{CH}_{3}\right)$ \\
\hline $1034 \mathrm{w}^{\mathrm{b}}$ & & $1032 \mathrm{~s}$ & $\rho\left(\mathrm{CH}_{3}\right)$ \\
\hline 1074 br $^{\mathrm{b}}$ & 1075 br & & $v_{\mathrm{as}}(\mathrm{ClO}) \mathrm{F}_{2}$ \\
\hline $1089 \mathrm{sh}^{\mathrm{b}}$ & & & $v_{\mathrm{as}}(\mathrm{ClO}) \mathrm{F}_{2}$ \\
\hline $1300 \mathrm{w}^{\mathrm{b}}$ & & $1294 \mathrm{sh}$ & $\delta_{\mathrm{s}}(\mathrm{HCH})$ \\
\hline $1313 \mathrm{w}^{\mathrm{b}}$ & & $1311 \mathrm{w}$ & $\delta_{\mathrm{s}}(\mathrm{HCH})$ \\
\hline \multicolumn{4}{|l|}{$1322 \mathrm{w}^{\mathrm{b}}$} \\
\hline $1405 \mathrm{~m}^{\mathrm{b}}$ & & $1406 \mathrm{vw}$ & $\delta_{\mathrm{as}}(\mathrm{HCH})$ \\
\hline $1419 \mathrm{w}^{\mathrm{b}}$ & & $1419 \mathrm{~s}$ & $\delta_{\text {as }}(\mathrm{HCH})$ \\
\hline $1445 \mathrm{sh}^{\mathrm{b}}$ & & $1437 \mathrm{~m}$ & $\delta_{\mathrm{as}}(\mathrm{HCH})$ \\
\hline $3013 \mathrm{sh}^{\mathrm{b}}$ & & $2991 \mathrm{~m}$ & $v_{\text {as }}(\mathrm{CH})$ \\
\hline
\end{tabular}

$v w$ very weak, $w$ weak, $s h$ shoulder, $m$ medium, $s$ strong, $v s$ very strong, $v$ stretching, $\rho$ rocking, $\delta$ scissoring, $\beta$ bending-in-plane, $\gamma$ bending-outof-plane, $T$ torsion

The unperturbed tetrahedral $\mathrm{ClO}_{4}^{-}$anion has nine normal modes. The vibrational representation of $\mathrm{ClO}_{4}^{-}$under $T_{\mathrm{d}}$ point group is: $\Gamma_{\text {vib }}=A_{1}+E+2 F_{2}$. Thus, an isolated $\mathrm{ClO}_{4}^{-}$ anion has four vibration frequencies (in wavenumbers): $v_{1}=$
$v_{\mathrm{s}}(\mathrm{ClO}) A_{1}=928 \mathrm{~cm}^{-1}, \quad v_{2}=\delta_{\mathrm{d}}(\mathrm{OClO}) E=459 \mathrm{~cm}^{-1}$, $v_{3}=v_{\mathrm{as}}(\mathrm{ClO}) F_{2}=1119 \mathrm{~cm}^{-1}$ and $v_{4}=\delta_{\mathrm{d}}(\mathrm{OClO}) F_{2}=$ $625 \mathrm{~cm}^{-1}$. All of them are Raman active, but only two of them: $v_{3}$ and $v_{4}$, of $F_{2}$ symmetry, are infrared active [10, 13-15]. 
The experimental IR fundamental frequencies for $\left[\mathrm{Fe}\left(\mathrm{OS}\left(\mathrm{CH}_{3}\right)_{2}\right)_{6}\right]\left(\mathrm{ClO}_{4}\right)_{2}$ are reported in Table 2. The assignment of the bands is based on the well-characterized spectra of dimethyl sulfoxide [13, 15-17], perchlorate anion [15] and the vibrational spectra of $\left[\mathrm{Fe}\left(\mathrm{OS}\left(\mathrm{CH}_{3}\right)_{2}\right)_{6}\right]\left(\mathrm{ClO}_{4}\right)_{2}$ obtained experimentally and presented in [8-10].

\section{Molecular motions}

\section{FT-FIR investigations}

The Fourier transform far-infrared (FT-FIR) spectra of title compound within the wavenumber range of $500-50 \mathrm{~cm}^{-1}$ were registered during heating and cooling of the sample in the temperature range of 280-350 and 20-350 K, respectively. The selected FIR spectra recorded for title compound in the temperature range of $280-350 \mathrm{~K}$ are illustrated in Fig. 5. The spectrum registered at $280 \mathrm{~K}$ in the range of $295-190 \mathrm{~cm}^{-1}$ contains four main bands (denoted by dotted lines in Fig. 5). Two of them: at 286 and at $265 \mathrm{~cm}^{-1}$ are connected with the $\delta$ (CSC) scissoring vibrational modes, and two at 227 and at $212 \mathrm{~cm}^{-1}$ are connected with the $T(\mathrm{CS})$ ligand torsional modes. At $350 \mathrm{~K}$, only two bands are visible in the mentioned regions. As can be seen in Fig. 5 below the PT temperature the intensity of the band at $286 \mathrm{~cm}^{-1}$ increases and the band at $220 \mathrm{~cm}^{-1}$ splits into two components. These characteristic changes of the FT-FIR spectra may suggest that the symmetry of $\left[\mathrm{Fe}\left(\mathrm{OS}\left(\mathrm{CH}_{3}\right)_{2}\right)_{6}\right]^{2+}$ lowers below the $T_{\mathrm{c}}$ temperature.

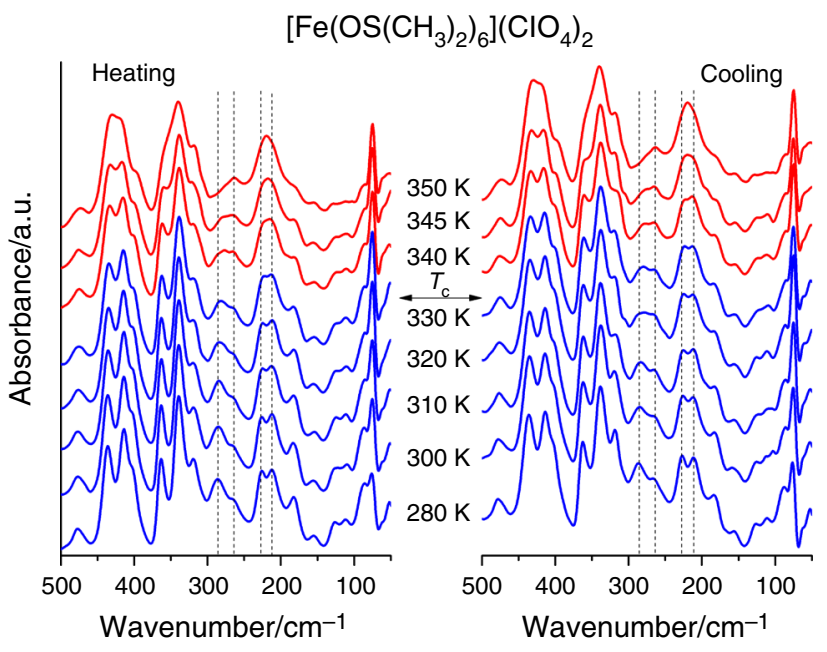

Fig. 5 Thermal evolution of the FT-FIR spectrum of $\left[\mathrm{Fe}\left(\mathrm{OS}\left(\mathrm{CH}_{3}\right)_{2}\right)_{6}\right]\left(\mathrm{ClO}_{4}\right)_{2}$ recorded upon heating and cooling in the wavenumber range of $500-50 \mathrm{~cm}^{-1}$. Temperature of the phase transition at $T_{\mathrm{c}}$ is marked by horizontal arrow, and the IR bands, which split or disappear with increasing temperature, are denoted by vertical dashed line
To determine whether the observed phase transitions are correlated with changes in the reorientational dynamics of the $\mathrm{OS}\left(\mathrm{CH}_{3}\right)_{2}$ ligands and/or of the $\mathrm{ClO}_{4}^{-}$anions, we followed the analysis of the full width at half maximum (FWHM) described by Carabatos-Nedelec and Becker, which is based on the theory used for the damping associated with an order-disorder mechanism [18, 19]. The reorientational correlation time $\tau_{\mathrm{R}}$ is the mean time between the instantaneous jumps from one potential well to the other, and it is defined by the following formula:

$\tau_{\mathrm{R}}=\tau_{\infty} \exp \left(\frac{E_{\mathrm{a}}}{k_{\mathrm{B}} T}\right)$

where $\tau_{\infty}$ is the relaxation time at an infinite temperature $T$, energy activation $E_{\mathrm{a}}$ is the potential barrier height for reorientation and $k_{\mathrm{B}}$ is the Boltzmann constant. When $\omega^{2} \tau_{\mathrm{R}}^{2} \gg 1$, where $\omega=2 \pi \nu$ is the frequency of a particular phonon mode, the temperature dependence of the FWHM is determined by following expression $[19,20]$ :

$\mathrm{FWHM}=(a+b T)+c \exp \left(-\frac{E_{\mathrm{a}}}{R T}\right)$

where $a, b, c$ and $E_{\mathrm{a}}$ are the fitting parameters. Here the $E_{\mathrm{a}}$ is the activation energy of the reorientation process, $R=N_{\mathrm{A}} k_{\mathrm{B}}$ is gas constant and $N_{\mathrm{A}}$ is Avogadro's constant. The linear part of Eq. (2) corresponds to the vibrational relaxation, and the exponential term corresponds to the reorientational relaxation. The last one is connected with thermal molecular reorientational motions of a diffusion nature.

The temperature dependence of the FWHM of the IR band at $339 \mathrm{~cm}^{-1}$, assigned to the $\tau(\mathrm{CSC})$ mode, is presented in Fig. 6. The FWHM was obtained by fitting with

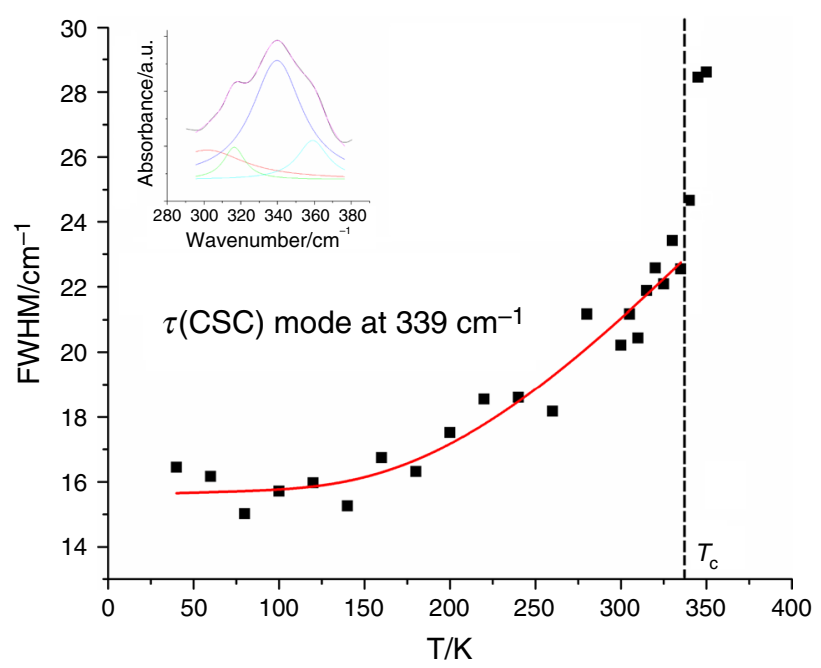

Fig. 6 Temperature dependence of the infrared bandwidth (FWHM) connected with $\tau(\mathrm{CSC})$ mode. Solid red line represents fitting of Eq. (2) to the experimental points. Dash vertical line denotes phase transition temperature $T_{\mathrm{c}}$ registered by DSC upon cooling. (Color figure online) 
Table 3 Fitted parameters $a, b, c$ and $E_{\mathrm{a}}$ for the temperature dependence of the FWHM of the IR band connected with $\tau$ (CSC) and $\delta_{\mathrm{d}}(\mathrm{OClO}) F_{2}$ modes

\begin{tabular}{llll}
\hline Parameters & $\begin{array}{l}\text { Band at } 339 \mathrm{~cm}^{-1} \\
\tau(\mathrm{CSC})\end{array}$ & $\begin{array}{l}\text { Band at } 620 \mathrm{~cm}^{-1} \\
\delta_{\mathrm{d}}(\mathrm{OClO}) \mathrm{F}_{2}\end{array}$ \\
\cline { 3 - 4 } & $\mathrm{I}$ & $\mathrm{I}$ & $\mathrm{II}$ \\
\hline$a\left(\mathrm{~cm}^{-1}\right)$ & 15.6 & 10.6 & 13.0 \\
$b\left(\mathrm{~cm}^{-1} \mathrm{~K}^{-1}\right)$ & $1.5 \times 10^{-3}$ & $-1.2 \times 10^{-3}$ & 1.8 \\
$c\left(\mathrm{~cm}^{-1}\right)$ & 77.1 & 117.8 & $-1.7 \times 10^{3}$ \\
$E_{\mathrm{a}}\left(\mathrm{kJ} \mathrm{mol}^{-1}\right)$ & 6.8 & 10.0 & 2.9 \\
\hline
\end{tabular}

the Lorentz function, and a typical deconvolution of the spectrum at $350 \mathrm{~K}$ is illustrated in the inset. In Fig. 6 the solid line is fitted to experimental points by Eq. (2), and the fitting parameters are listed in Table 3. We observe a large reduction in the FWHM value at $T_{\mathrm{c}}$ and with decreasing of temperature the FWHM values exponentially decrease. The former observation indicates that the rate of reorientational motions changes abruptly at $T_{\mathrm{c}}$. The latter provides the activation energy for the rotational motion of ligands $E_{\mathrm{a}}=6.8 \pm 1.7 \mathrm{~kJ} \mathrm{~mol}^{-1}$. At the low-temperature end, the FWHM becomes almost constant, and even starts to increase, indicating that only the vibrational relaxation process is involved.

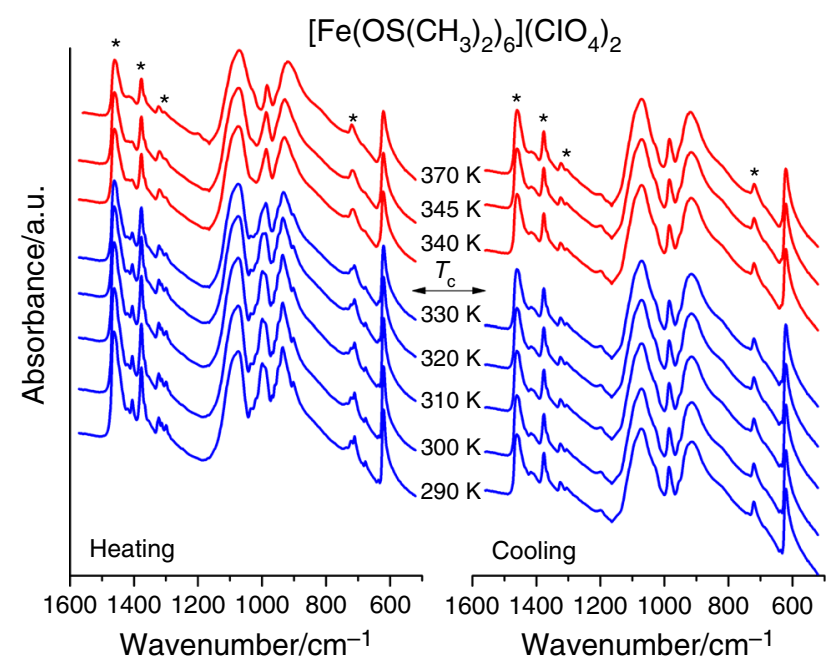

Fig. 7 Thermal evolution of the FT-MIR spectrum recorded for $\left[\mathrm{Fe}\left(\mathrm{OS}\left(\mathrm{CH}_{3}\right)_{2}\right)_{6}\right]\left(\mathrm{ClO}_{4}\right)_{2}$ upon heating and cooling in the wavenumber range $1600-500 \mathrm{~cm}^{-1}$. Temperatures of the phase transitions at $T_{\mathrm{c}}$ are marked by horizontal arrows, and the asterisks indicate Nujol vibrations

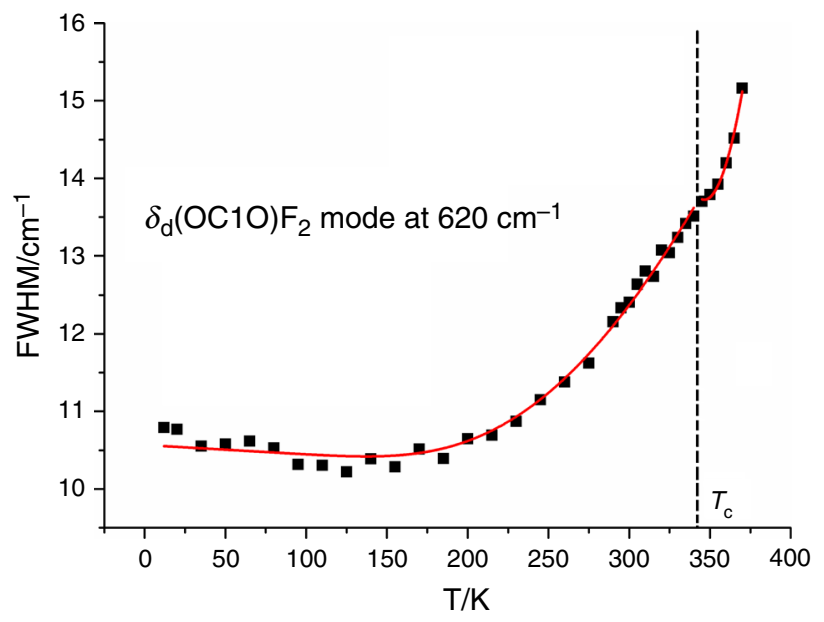

Fig. 8 Temperature dependence of the infrared bandwidth (FWHM) connected with $\delta_{\mathrm{d}}(\mathrm{OClO}) \mathrm{F}_{2}$ mode. Solid red lines represent fitting of Eq. (2) to the experimental points. Dash vertical line denotes phase transition temperature $T_{\mathrm{c}}$ registered by DSC upon cooling. (Color figure online)

\section{FT-MIR investigations}

The FT-MIR spectra of $\left[\mathrm{Fe}\left(\mathrm{OS}\left(\mathrm{CH}_{3}\right)_{2}\right)_{6}\right]\left(\mathrm{ClO}_{4}\right)_{2}$ were obtained in the spectral range of $4000-500 \mathrm{~cm}^{-1}$ during heating and subsequently cooling the sample in the temperature range of $290-370$ and $12-370 \mathrm{~K}$, respectively. Figure 7 presents selected MIR spectra registered for $\left[\mathrm{Fe}\left(\mathrm{OS}\left(\mathrm{CH}_{3}\right)_{2}\right)_{6}\right]\left(\mathrm{ClO}_{4}\right)_{2}$ in the range of $1600-500 \mathrm{~cm}^{-1}$. No significant changes of the FT-MIR spectra at the phase transition temperature range can be seen, which suggests that the phase transition at $T_{\mathrm{c}} \approx 338 \mathrm{~K}$ is probably connected with changes of the reorientational dynamics of $\mathrm{CH}_{3}$ groups or $\mathrm{ClO}_{4}^{-}$anions.

Figure 8 demonstrates the temperature dependence of the FWHM of the band at $620 \mathrm{~cm}^{-1}$, associated with $\delta_{\mathrm{d}}(\mathrm{OClO}) F_{2}$ mode, and shows that during cooling the sample FWHM decreases exponentially down to the phase transitions region, next FWHM becomes discontinuous and during further cooling FWHM decreases exponentially down again till to ca. $170 \mathrm{~K}$, next it becomes almost constant indicating that only the vibrational relaxation process is involved. In Fig. 8 the solid line is fitted to experimental points by Eq. (2), and the fitting parameters are listed in Table 3. The estimated activation energy values for perchlorate anions are: $E_{\mathrm{a}}(\mathrm{I})=10.0 \pm 0.5 \mathrm{~kJ} \mathrm{~mol}^{-1}$ and $E_{\mathrm{a}}(\mathrm{II})=2.9 \pm 0.1 \mathrm{~kJ} \mathrm{~mol}^{-1}$ for the high- and low-temperature phase, respectively. 


\section{Conclusions}

The results obtained in this work have led us to the following conclusions:

1. $\left[\mathrm{Fe}\left(\mathrm{OS}\left(\mathrm{CH}_{3}\right)_{2}\right)_{6}\right]\left(\mathrm{ClO}_{4}\right)_{2}$ does not decompose until ca. $385 \mathrm{~K}$.

2. In the temperature range of $100-385 \mathrm{~K}$, it can exist in one of two states:

- phase Cr. 1 which is stable below $T_{\mathrm{c}}=338.3 \mathrm{~K}$, or

- phase Rot. 1 , which is stable above $T_{\mathrm{c}}=338.3 \mathrm{~K}$.

3. In the temperature range of 385-443 K, two parallel processes take place. The first one is the decomposition of $\left[\mathrm{Fe}\left(\mathrm{OS}\left(\mathrm{CH}_{3}\right)_{2}\right)_{6}\right]\left(\mathrm{ClO}_{4}\right)_{2}$ connected with releasing two DMSO molecules, and the second is dissolution of $\left[\mathrm{Fe}\left(\mathrm{OS}\left(\mathrm{CH}_{3}\right)_{2}\right)_{6-\mathrm{x}}\right]\left(\mathrm{ClO}_{4}\right)_{2}$ in released DMSO.

4. The characteristic changes of the FT-FIR spectra of $\left[\mathrm{Fe}\left(\mathrm{OS}\left(\mathrm{CH}_{3}\right)_{2}\right)_{6}\right]\left(\mathrm{ClO}_{4}\right)_{2}$ at the phase transition temperature $T_{\mathrm{c}}$ suggest that the phase transition Cr. 1 $\leftrightarrow$ Rot. 1 may be related to the crystal structure change, which is also confirmed by the presence of modes that disappear at the high-temperature phase.

5. From the temperature dependence of bandwidth FWHM of the infrared bands associated with the $\tau(\mathrm{CSC})$ and $\delta_{\mathrm{d}}(\mathrm{OClO}) F_{2}$ vibrational modes, we can conclude that the reorientational motions of DMSO molecules, and $\mathrm{ClO}_{4}^{-}$anions contribute to the phase transition mechanism. These groups perform fast stochastic reorientational motions just above $T_{\mathrm{c}}$. The estimated activation energy value for reorientation of DMSO molecules in low-temperature phase is: $E_{\mathrm{a}}=6.8 \pm 1.7 \mathrm{~kJ} \mathrm{~mol}^{-1}$, and activation energy values of $\mathrm{ClO}_{4}^{-}$anions in the low- (I) and high-temperature (II) phases are: $E_{\mathrm{a}}(\mathrm{I})=10.0 \pm 0.5 \mathrm{~kJ} \mathrm{~mol}^{-1}$ and $E_{\mathrm{a}}(\mathrm{II})=2.9 \pm 0.1 \mathrm{~kJ} \mathrm{~mol}^{-1}$.

Acknowledgements The infrared absorption (FT-FIR and FT-MIR) researches were carried out with the equipment purchased thanks to the financial support of the European Regional Development Fund in the framework of the Polish Innovation Economy Operational Program (Contract No. POIG.02.01.00-12-023/08).

Open Access This article is distributed under the terms of the Creative Commons Attribution 4.0 International License (http://crea tivecommons.org/licenses/by/4.0/), which permits unrestricted use, distribution, and reproduction in any medium, provided you give appropriate credit to the original author(s) and the source, provide a link to the Creative Commons license, and indicate if changes were made.

\section{References}

1. Migdal-Mikuli A, Mikuli E, Szostak E, Serwońska J. Phase polymorphism of $\left[\mathrm{Cd}(\mathrm{DMSO})_{6}\right]\left(\mathrm{ClO}_{4}\right)_{2}$ studied by differential scanning calorimetry. Z Naturforschung. 2003;58a:341-5.

2. Migdał-Mikuli A, Szostak E. Phase polymorphism of $\left[\mathrm{Co}(\mathrm{DMSO})_{6}\right]\left(\mathrm{ClO}_{4}\right)_{2}$ studied by differential scanning calorimetry. Thermochim Acta. 2005;426:191-8.

3. Migdał-Mikuli A, Szostak E. Phase polymorphism of $\left[\mathrm{Mn}(\mathrm{DMSO})_{6}\right]\left(\mathrm{ClO}_{4}\right)_{2}$ studied by differential scanning calorimetry. Z Naturforschung. 2005;60a:289-95.

4. Migdał-Mikuli A, Szostak E. Phase polymorphism of $\left[\mathrm{Zn}(\mathrm{DMSO})_{6}\right]\left(\mathrm{ClO}_{4}\right)_{2}$ studied by differential scanning calorimetry. Thermochim Acta. 2006;444:195-200.

5. Migdał-Mikuli A, Szostak E. Phase polymorphism of $\left[\mathrm{Ni}(\mathrm{DMSO})_{6}\right]\left(\mathrm{ClO}_{4}\right)_{2}$ studied by differential scanning calorimetry. Z Naturforschung. 2007;62:1-8.

6. Szostak E, Migdał-Mikuli A. Phase polymorphism and thermal decomposition of hexadimethylsulphoxidemagnesium(II) chlorate(VII). J Therm Anal Calorim. 2010;101:601-6.

7. Szostak E, Migdał-Mikuli A, Bernard P. Thermal analysis, phase transitions and molecular reorientations in $\left[\mathrm{Sr}\left(\mathrm{OS}\left(\mathrm{CH}_{3}\right)_{2}\right)_{6}\right](-$ $\left.\mathrm{ClO}_{4}\right)_{2}$. J Therm Anal Calorim. 2014;115:443-9.

8. Selbin J, Bull WE, Holmes LH Jr. Metallic complexes of dimethylsulphoxide. J Inorg Nucl Chem. 1961;16:219-24.

9. Currier WF, Weber JH. Complexes of sulfoxides. I. Octahedral complexes of manganese(II), iron(II), cobalt(II), nickel(II), and zinc(II). Inorg Chem. 1967;6:1539-43.

10. Berney CV, Weber JH. Complexes of sulfoxides. II. Metal-oxygen stretching vibrations in complexes of dimethyl sulfoxide and dimethyl sulfoxide-d6 and the point group of the cation. Inorg Chem. 1968;7:283-7.

11. Migdał-Mikuli A, Górska N. Thermal behaviour of $\left[\mathrm{Mg}(\mathrm{DMSO})_{6}\right]\left(\mathrm{NO}_{3}\right)_{2}$. J Therm Anal Calorim. 2007;90:833-9.

12. Górska N, Inaba A, Migdał-Mikuli A. Phase behaviour of crystalline $\left[\mathrm{Cr}(\mathrm{DMSO})_{6}\right]\left(\mathrm{BF}_{4}\right)_{3}$ studied by adiabatic calorimetry and FT-IR spectroscopy. Vib Spectrosc. 2012;62:222-8.

13. Schrader B, Meier W. Raman/IR Atlas. Weinheim: Verlag Chemie GmbH; 1974.

14. Szostak E, Drużbicki K, Mikuli E. Molecular structure and vibrational spectrum of $\left[\mathrm{Mg}\left(\left(\mathrm{CH}_{3}\right)_{2} \mathrm{SO}\right)_{6}\right]\left(\mathrm{ClO}_{4}\right)_{2}$ studied by infrared and Raman spectroscopies and DFT computations. J Mol Struct. 2010;970:139-46.

15. Nakamoto K. Infrared and Raman spectra of inorganic and coordination compounds. Part B. 6th ed. Hoboken: Wiley; 2009.

16. Cotton FA, Francis R, Horrocks WD. Sulfoxides as ligands. II. The infrared spectra of some dimethyl sulfoxide complexes. J Phys Chem. 1960;64:1534-6.

17. Skripkin MY, Lindqvist-Reis $P$, Abbasi A, et al. Vibrational spectroscopic force field studies of dimethyl sulfoxide and hexakis (dimethyl sulfoxide) scandium(III) iodide, and crystal and solution structure of the hexakis (dimethyl sulfoxide) scandium(III) ion. Dalton Trans. 2004;23:4038-49.

18. Carabatos-Nédelec C, Becker P. Order-disorder and structural phase transitions in solid-state materials by Raman scattering analysis. J Raman Spectrosc. 1997;28:663-71.

19. Andrade PR, Rao AD, Katiyar RS, Porto SPS. Analysis of the relationship between temperature dependence of the libration mode and dielectric relaxation in $\mathrm{NaNO}_{2}$. Solid State Commun. 1973;12:847-51.

20. PR Andrade, Porto SPS. On linewidth of phonons associated to a disorder mechanism. Solid State Commun. 1973;13:1249-54. 